\title{
Reproductive response of a marine annelid to winter storms: an analog to fire adaptation in plants?
}

\author{
James P. Barry \\ A-001 Scripps Institution of Oceanography, La Jolla, California 92093, USA
}

\begin{abstract}
The recruitment strength of Phragmatopoma lapidosa californica, a gregarious, sedentary, tube-building polychaete from shallow marine habitats along the open coast of California, was significantly correlated to wave disturbance intensity during the previous 2 to 5 mo. This relationship appears to be caused by a reproductive behavior whereby individuals respond to disastrous wave disturbance events by releasing gametes into the water column. Individuals thus maximize reproductive effort when faced with an increase in both the probability of death and the availability of settlement space. The life history characteristics of $P$. l. californica indicate that it is well-adapted for persistence in a frequently disturbed environment. These adaptations are analogous to those exhibitied by several species of terrestrial plants in fire-disturbed communities. Intense wave events and fires are analogous disturbances in that both have similar temporal patterns, ecological effects, and exert similar selection pressures on species in each community
\end{abstract}

\section{INTRODUCTION}

Physical disturbance plays a fundamental role in the dynamics of natural communities. To persist in a community, species must possess adaptations which allow them to resist or recover from even the most severe disturbances encountered. These adaptations can include resistant structures to minimize disturbancerelated mortality and reproductive patterns to allow post-disturbance recolonization. In addition, many species apparently rely on disturbances to disrupt the competitive monopolization of resources by dominant species (Pickett \& White 1985). For species highly susceptible to physical disturbances which also rely on disturbances to free resources necessary for growth or reproduction or both, the selective pressures for specific responses to individual disturbances may be very strong. For example, many species in fire-disturbed terrestrial communities have mechanisms to respond to disastrous fires by seed release, seed germination, or post-fire flowering (Muller et al. 1968, Biswell 1974, Gill 1981). These processes maximize recruitment strength by coupling reproductive release with a reduction in light competition, allelopathy, and other factors which inhibit seedling survivorship (Frost 1984). Other examples of fire adaptations include fire retardant bark and root sprouting (Christensen 1985). In this frequently and intensively disturbed environment, many species have life history patterns which are tightly coupled to fire effects.

Such evolutionarily-derived responses to disasters (sensu Harper 1977) are well documented from firedisturbed terrestrial plant communities (Christensen 1985) but are little-known in marine systems. Shallow water marine communities, however, are analogous to fire-adapted plant communities in that disastrous storms and fires have similar frequencies, severities, and in many ways exert similar selection pressures on species in this community. Both fires and severe storms are generally predictable as to season, yet are unpredictable on an interannual time scale; during any year fires and intense storms usually occur in summer and winter, respectively, but disturbances at a particular location do not occur each year and may occur infrequently. Species in both habitats encounter similar ecological problems related to successful reproduction. For many species, intraspecific and interspecific competition for space effectively prevents the successful 
recruitment of seedings or juveniles to the adult population. Disturbances which reduce such competition may be a requisite for recruitment. In marine systems, overgrowth and eventual dominance by the mussel Mytilus californianus is known to inhibit the settlement or successful recruitment of barnacles and other inferior competitors for space, except where wave disturbance creates gaps in mussel beds (Paine 1974, 1979). Examples of such phenomena are common in many communities (see Pickett \& White 1985).

Like fire-adapted terrestrial species, coastal marine species must adapt to severe wave-induced disturbance by resistance or recovery. Physical attributes such as low profiles, hard shells, and other robust structures which are resistant to abrasion or breakage, decrease waveinduced mortality for some species. Shells of intertidal limpets vary in their ability to withstand damage caused by wave-borne rocks and their intertidal distribution are related to the frequency and intensity of wave-induced damage (Shanks \& Wright 1986). Several marine species (many algae and colonial invertebrates) are capable of regrowing from holdfasts or basal parts that may remain after storms and can thereby recover rapidly. Alternatively, because wave damage is generally highest during winter, species which recruit during late winter or spring may experience higher survivorship or lower competition for space or both, than in other seasons (Young 1942, 1946, Dayton 1975, Paine \& Levin 1981, Suchanek 1981). In order to maximize reproductive success, individuals should respond to environmental cues which are indicative of an increase in the probability of successful recruitment. Species that concentrate reproductive output following disturbances that reduce resource competition may realize higher reproductive success than those that do not; such disturbance-linked reproductive effort may be particularly important for inferior competitors. Likewise, if there is a potential increase in fitness, cues indicative of a high probability of death should provoke an immediate reproductive release or effort.

In this paper, I present evidence that Phragmatopoma lapidosa californica, a polychaete worm found on the open coast of California, exhibits a spawning response to damage from intense storms. This behavior allows $P$. l. californica to maximize reproductive effort when the likelihood of recruitment success and the probability of adult mortality are high. P. 1 . californica is highly vulnerable to wave-induced mortality and spawns in response to injury or damage to colonies produced by severe storms. Because resistance to storm damage is low and the potential for recruitment is, in part, dependent upon the creation of open space by disturbance, $P$. 1 . californica appears to concentrate its reproductive effort according to environmental cues.

\section{Coastal California wave climate}

The shallow water communities along the southern California coast are intermittently exposed to intense storms with extremely high waves $(>6.0 \mathrm{~m})$ which are often associated with El Niño-Southern Oscillation (ENSO) events (Seymour et al 1984). During the past 80 yr, extreme wave events capable of devastating coastal communities have occurred infrequently (Fig. 1), yet

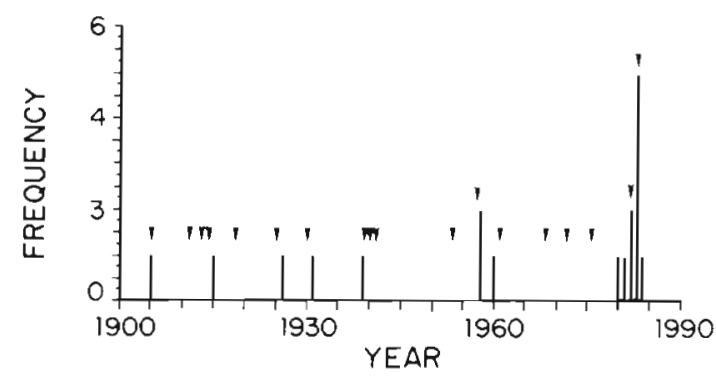

Fig. 1. Frequency of extreme large wave events in southern California from 1905 to 1985 (data from Seymour et al. 1984). Data represent number of days per year with a wave height greater than $6.0 \mathrm{~m}$. Arrows indicate the years of onset for moderate to strong El Niño events (Seymour et al. 1984)

often enough to predictably affect the long-lived species of these communities.

The relationship between wave height and physical damage to coastlines and shallow water communities is complex. In theory, the energy flux associated with waves is related roughly to the square of the wave height. Due, however, to synergistic factors such as storm surge, edge wave generation, and the coincidence of extreme high tides, this relationship may actually be closer to wave height to the third or even fifth power (R. Guza pers. comm.), indicating an even greater potential for disturbance for large wave events. Extreme wave events have been unusually frequent in the past decade and the 1982-1983 winter storms were perhaps the most intense prolonged series of storms during this century. A time series of daily maximum significant wave heights from a wave-measuring buoy located $10 \mathrm{~km}$ south of the study site (Anon 1978-1987) is shown in Fig. 2. During the 1982-1983 storms, many communities were severely impacted; at several intertidal sites extensive areas were denuded of biota by wave surge and scour from rolling boulders.

\section{Phragmatopoma lapidosa californica life history}

Phragmatopoma lapidosa californica is a member of the Sabellariidae, a small polychaete family distributed worldwide. This species, formerly classified as $P$. californica (Pawlik 1988), is distributed from the middle 


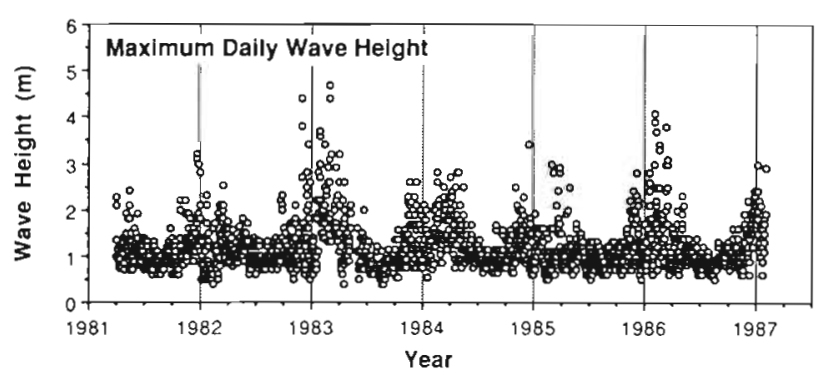

Fig. 2. Daily significant maximum wave height at the Mission Bay Buoy (Coastal Data Information Program, 1978-1987). Each data point represents the maximum $1 / 3$ of the waves at the sites during each date

intertidal to shallow subtidal in rocky and sandy habitats from central California to Panama (Kirtley 1968, Morris et al. 1980). In littoral habitats it forms aggregations about 5 to $50 \mathrm{~cm}$ thick covering up to several $\mathrm{m}^{2}$ or is distributed as scattered prostrate individuals. Subtidally, aggregations (reefs) as large as several hundred $\mathrm{m}^{2}$ have been observed by divers throughout the southern California bight (for example, near southeastern San Nicolas Island and southern San Miguel Island; J. Estes pers. comm.). Individual tubes are constructed of cemented sand grains and are relatively fragile. Aggregations persist for several months to years, but are eventually broken by waves, rolling boulders or cobbles, or competition with other species (pers. obs.). Aggregations of other reef-forming sabellariids are similarly damaged by waves (Wilson 1971, Gruet 1986).

Phragmatopoma lapidosa californica is dioecious, and forms aggregations of mixed sexes. They are sexually mature all year, and spawning can be induced in the laboratory or from field-collected individuals during any time of the year (Jensen 1986). Spawning of gametes into the water can be easily induced by breakage of or removal of individuals from their sand tubes or by agitation of pieces of the colony in seawater (J. Pawlik pers. comm.). The former technique is commonly used to collect gametes from P. 1. californica for laboratory study (Wilson 1929, Eckelbarger 1975, Jensen \& Morse 1984, Jensen 1986, Pawlik 1986). Fertilization occurs in the water column and trochophore larvae are competent to metamorphose to a demersal adult form after 2 to $8 \mathrm{wk}$ or more (Dales 1952, Eckelbarger 1977). Competent larvae may be able to remain in the plankton for several months until a suitable settlement surface is encountered. Larvae of Sabellaria alveolata, a member of the Sabellaridae with a nearly identical developmental cycle, are thought to remain competent in the plankton for up to 11 mo (Wilson 1971). Spawning of P. 1. californica appears to be seasonal and larvae are most abundant in the plankton during winter and spring (Jensen 1986). Although settlement also can occur during any time of the year, it too is generally much more intense during winter and spring (Taylor \& Littler 1982, Swarbrick 1984, Jensen 1986). Larvae preferentially metamorphose on the sand tubes of adult conspecifics (Jensen \& Morse 1985); however, settlement on bare rock does occur Metamorphosis is chemically-induced by compounds isolated from the sand tubes (Pawlik 1986, Pawlik \& Faulkner 1986), leading to gregarious recruitment and colony formation. Because asexual budding does not occur in P. 1. californica, colonies are formed only by recruitment of individuals from the plankton. Sexual maturity occurs as early as 1 to $3 \mathrm{mo}$ after settlement; individuals are iteroparous and like Sabellaria alveolata (Wilson 1971). may live for 7 yr or more. Sabellariids found along the European coast which form large aggregations are also sexually active nearly all year and have seasonal peaks in fecundity and the release of gametes (Wilson 1970, Curtis 1978, Eckelbarger 1978, Gruet \& Lassus 1983).

\section{METHODS AND MATERIALS}

Because the life history and reproductive behavior of Phragmatopoma lapidosa californica suggested that its recruitment and survivorship may be coupled to wave disturbance, I compared its intertidal abundance and recruitment rate to the recent history of wave disturbance for the habitat, using a cross correlation analysis. I monitored the abundance of $P$. 1 . californica on a flat intertidal reef in La Jolla, California following the 1982-1983 winter storms until late 1986. Fourteen plots were established at haphazard locations on an exposed intertidal reef flat by tossing a quadrat onto sections of the reef; nails were used to mark the corners of the plots, which were otherwise unmanipulated. Photographs of these $0.7 \times 0.7 \mathrm{~m}$ plots were taken about 4 times per year. The percentage cover of the dominant biota (including $P$. l. californica) was quantified by computer-assisted planimetry of individuals or patches from photographic slides projected onto a digitizing pad. P. 1. californica settlement was widespread over the reef in 1983, but on flat habitats with little vertical relief, percentage cover decreased during the next several months and most plots became dominated by upright coralline algae (Corallina sp.). Whiplash damage by algal thalli apparently was the major cause for the reduction in $P .1$. californica cover in these microhabitats. Percentage cover in these plots was thus indicative of recent recruitment, rather than persistent cover of older individuals. Locations with greater relief (near boulders, etc.) and higher sand cover provide more physical support and often allow $P$. 1 . californica to overgrow and thereby outcompete other species (Taylor \& Littler 1982). 
I compared the time series of the percentage cover of Phragmatopoma lapidosa californica to wave power, calculated from the maximum daily wave height observations (Anon 1978-1987). Wave power, rather than wave height, was used in order to better estimate the potential of wave energy as a disturbance force. Wave power in kilowatts per $m$ shoreline was estimated from the equation:

$$
\text { Power }=1 / 8 \rho g \mathrm{H}^{2}(g \mathrm{D})^{0.5}
$$

where $\rho=$ water density $\left(1025.0 \mathrm{~kg} \mathrm{~m} \mathrm{~m}^{-3}\right) ; g=$ gravitational acceleration $\left(9.81 \mathrm{~m} \mathrm{~s}^{-2}\right) ; \mathrm{H}=$ wave height $(\mathrm{m})$; $\mathrm{D}=$ water depth (m) (McLellan 1965). Wave power was partially weighted by tidal height by substituting the observed maximum daily sea level at the Scripps Institution of Oceanography pier (National Ocean Survey) for $D_{i}$ thus, large wave events which coincided with extremely high tides caused a proportionally higher energy flux across coastal communities. The time series of percentage cover for $P$. 1 . californica $(n=16)$ was compared to daily records of wave power using a product-moment correlation coefficient $(r)$, calculated by pairing each percentage cover observation (arcsinetransformed) with the maximum wave power during the preceding $45 \mathrm{~d}$ 'window', for a range of time lags from 0 to $900 \mathrm{~d}(30 \mathrm{mo})$. In effect, each measurement of $P$. 1 . californica abundance was compared to the most intense recent disturbance, with the expectation that if P. l. californica responds to wave disturbance by higher recruitment rates (with some time lag), its abundance on the reef will increase following intense disturbances.

Several other factors may influence the recruitment rates and intertidal abundance of Phragmatopoma lapidosa californica. These include factors which regulate the spawning patterns and fecundity of adults as well as the growth, survival, and transport of larvae. I compared the percentage cover of $P$. 1. californica to the monthly mean index of coastal upwelling calculated near San Diego, California $\left(33^{\circ} \mathrm{N}, 119^{\circ} \mathrm{W}\right)$ (National Marine Fisheries Service), and to the monthly anomaly from the seasonally adjusted mean index (1948-1967 mean). Because upwelling may inhibit the rate of recruitment for some coastal invertebrates by decreasing the shoreward flux of larvae (Roughgarden et al. 1987, Ebert \& Russell 1988), lower recruitment to the shore is expected during periods of greatest upwelling and relatively higher recruitment when upwelling is reduced; accordingly, the expected correlation between these factors, if any, is negative. Monthly mean sea surface temperatures, the anomaly from the long-term mean, and the monthly mean chlorophyll a concentration, all measured at the Scripps Institution of Oceanography pier, were also compared to the time series of percentage cover. These parameters may be related to the survival and growth of larvae, which affects their subsequent recruitment and abundance in the intertidal.

Stepwise multiple regression analysis of arcsine transformed cover of Phragmatopoma lapidosa californica and those factors which were shown to be individually most closely correlated to its percentage cover were used to identify combinations of factors that may be potentially important to $P$. l. californica recruitment. Wave power, upwelling index, chlorophyll a concentration, and sea surface temperature (correlated with settlement density; Jensen 1986) were analysed for time lags of 0,3 , and $5 \mathrm{mo}$; these time lags were chosen for the high correlation of individual parameters with percentage cover of $P$. $l$. californica.

The abundance of larvae, the availability of suitable settlement sites, and predation on larvae and juveniles, all affect the recruitment rates of Phragmatopoma lapidosa californica and other intertidal invertebrates. In that the intensity of predation on juveniles appears to be low over the reef, if the abundance of $P . l$. californica larvae remains high, any increase in space for settlement should result in the recruitment of individuals to the reef. In order to assess the importance of settlement space (relative to larval abundance), I simulated natural disturbance on the intertidal reef flat during the winter or spring of 1983, 1984, and 1985 to artificially increase the availability of settlement space. During each year, I scraped most or all of the algal and invertebrate cover from each of 10 to 20 plots $(0.15 \times$ $0.15 \mathrm{~m}$ ) in a manner similar to the effects of scouring by boulders during storms. The set of quadrats for each year were positioned haphazardly or randomly and the corners of each quadrat marked with nails. During each visit in the following years I measured the percentage cover of identifiable biota from direct observations or from photographic slides, using 50 to 100 point contacts per quadrat. Direct measurements of the abundance of larvae in the plankton were not made during this study.

\section{RESULTS}

The percentage cover of Phragmatopoma lapidosa californica on the intertidal reef (Fig. 3a) was highly correlated $(r>0.74, p<0.01)$ to wave power (Fig. $3 b$ ) 2.5 to 5 mo earlier (Fig. 4). Recruitment in the quadrats was heavy following the severe storms of 1982-1983, then declined during the following year, and significant recruitment did not recur until after the large storms of the 1985-1986 winter. The highest correlation ( $r=0.93, p<0.001$ ) occurred with a lag of abundance by ca 5 mo after wave power. Higher lag periods showed no correlation between these parameters, suggesting the time from gamete release to recruitment is 

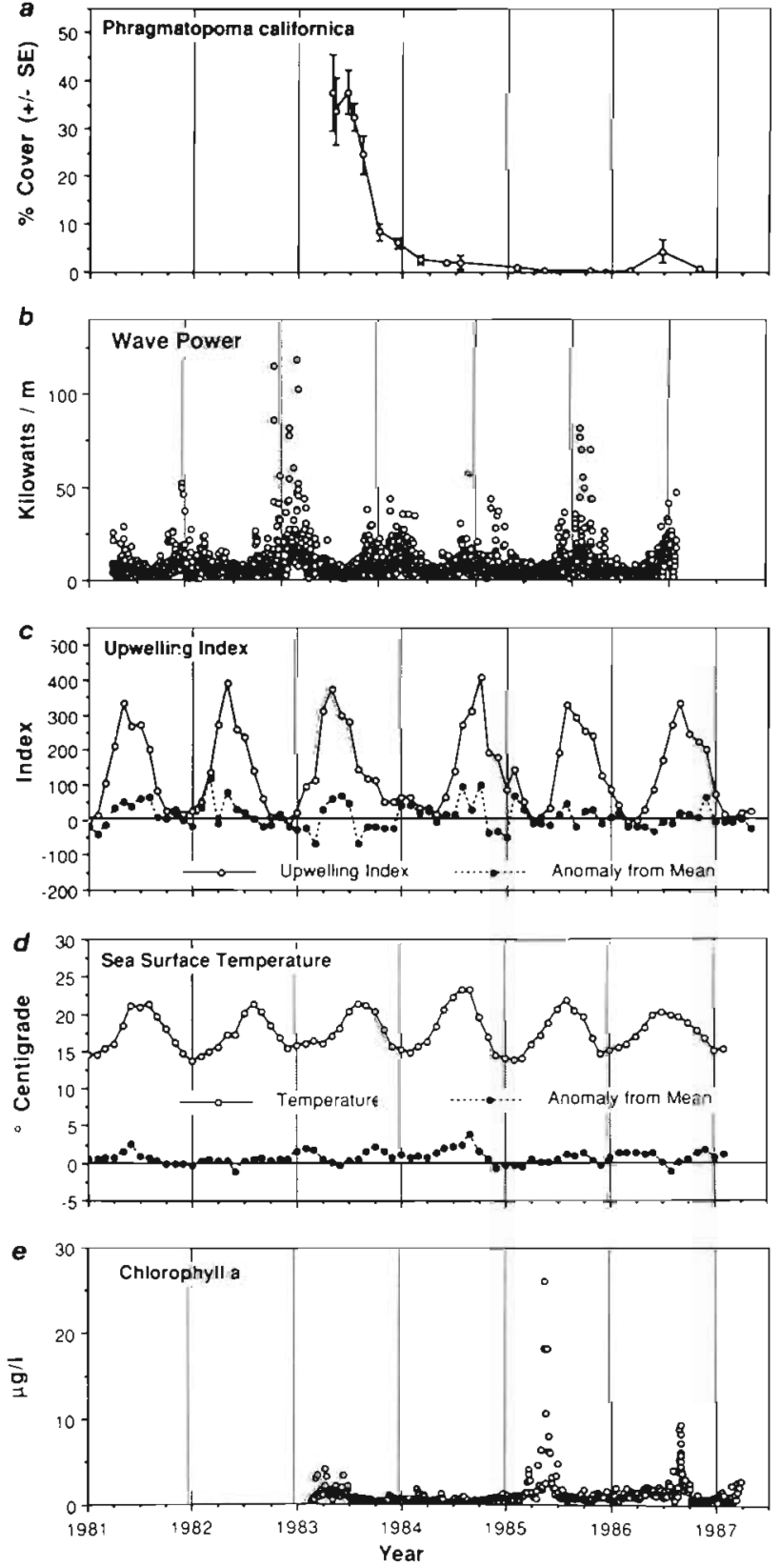

Fig. 3. Phragmatopoma lapidosa californica. Temporal patterns of abundance and several physical parameters. (a) Percentage cover P. l. californica in natural quadrats from 1983 to 1987. (b) Daily maximum tidal power near the study site. (c) Mean monthly index of coastal upwelling and the anomaly from the 1948 to 1967 mean. (d) Sea surface temperature and the anomaly from the long-term mean. (e) Chlorophyll a concentrations at the Scripps Institution of Oceanography pier

2.5 to 5 mo or less. In order to test whether the 4 observations of percentage cover during 1983 were primarily responsible for the high correlation, I excluded these points and repeated the correlation analysis; even without these data the correlation

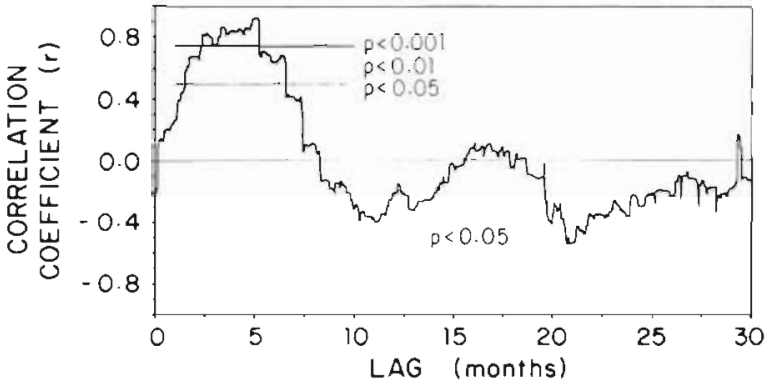

Fig. 4. Product-moment correlation coefficient between daily maximum wave power and percentage cover of Phragmatopoma lapidosa californica in unmanipulated intertidal quadrats

remained highly significant $(r=0.74, p<0.01)$. The correlation of percentage cover with the mean monthly (rather than daily) wave power was also highly significant $(p<0.01)$ for a range of lags from 3 to $5 \mathrm{mo}$.

Phragmatopoma lapidosa californica recruitment was particularly heavy at several intertidal locations along the California coast following the severe storms during winter and spring of 1983 (Fig. 3a). This exceptional recruitment event was evident at intertidal sites throughout San Diego County; the mean percentage cover in intertidal quadrats reached nearly $40 \%$. Near Santa Barbara, California, a well-studied intertidal boulder field, in which $P$. 1. californica was previously uncommon, was cemented into a solid reef of worm tubes and boulders by the inundation of recruits of $P . l$. californica (J. Connell pers, comm.). Similarly, its recruitment was heavy near Avila Beach, San Luis Obispo Co. (J. Blecca pers. comm.).

Although natural history observations and the high correlation indicate a relationship between wave disturbance and Phragmatopoma lapidosa californica recruitment, this information does not separate the relative importance of larval supply from the inhibition of settlement or recruitment by pre-emptive competition. Recruitment data from the artificially-cleared plots, however, indicated that changes in the abundance of larvae were primarily responsible for recruitment events for P. 1. californica. During 1983, recruitment to cleared quadrats mimicked that in the unmanipulated plots, reaching nearly $40 \%$ cover, then fell to near $0 \%$ within 1 yr (Fig. 5). When wave disturbance was minimal during 1984 and 1985, recruitment to cleared plots was also very low. This strongly suggests that larval abundance was also related to wave disturbance and limited the rate of recruitment to intertidal plots.

Larval survivorship and growth may be controlled by highly changeable factors such as upwelling patterns, temperature, and food availability, leading to variable levels of recruitment and abundance. The mean 


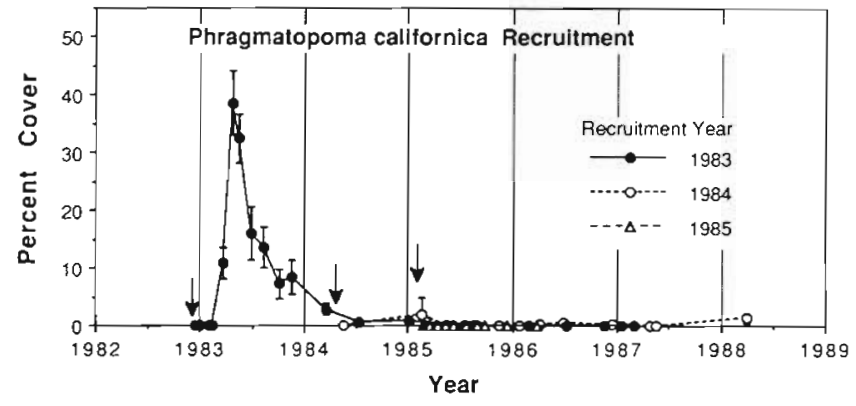

Fig. 5. Phragmatopoma lapidosa californica. Time series of abundance in intertidal quadrats artificially disturbed during 1983 to 1985. Arrows indicate date of each year when biota in quadrats were cleared

monthly index of coastal upwelling (Fig. 3c) was positively correlated to Phragmatopoma lapidosa californica abundance $(r=+0.66, p<0.01)$, with a 1 mo lag in larval abundance (Fig.6a). During early 1983, the upwelling index rose earlier than normal (1948-1967 mean), and coincided with the heavy recruitment of $P$. 1. californica. The anomaly from the mean (1948-1967) upwelling index (Fig. 3c) was also slightly significantly correlated $(r=0.53, p<0.05)$ with a 1 mo lag (Fig. 6b). This positive correlation is, however, contrary to the negative relationship expected due to the inhibition of larval settlement by upwelling-induced transport of larvae away from the coast. Exclusion of the 4 observations during the peak abundance of $P$. l. californica during 1983 reduces this correlation $(I)$ to less than 0.39 $(p>0.20)$.

Other factors potentially related to larval growth and survival were not significantly correlated to the percentage cover of Phragmatopoma lapidosa californica on the reef. The monthly mean sea surface temperature and the anomaly from the $60 \mathrm{yr}$ seasonally-adjusted mean, from the Scripps Institution of Oceanography pier (Fig.3d), were not correlated with the percentage cover of $P$. l. californica (maximum $r<0.46$ $p>0.05$ ), with time lags of 0 to 12 mo (Fig. $6 c$, d). The monthly mean concentration of chlorophyll $a$ at the Scripps Institution of Oceanography pier (Fig. 3e) is perhaps more indicative of larval food abundance than physical parameters, but was not correlate to $P .1$. californica abundance 0 to 6 mo later $(r<0.36$, $p>0.10$; Fig. 6e).

Stepwise multiple regression analyses of wave power, upwelling index, chlorophyll a concentration, and sea surface temperature on the percentage cover of Phragmatopoma lapidosa californica showed little or no improvement of its correlation to wave power alone. Table 1 shows partial correlation coefficients for factors which significantly affected the total correlation ( $p$ $<0.10$ ). Values for the 5 mo time lag are lower than the coefficient for wave power alone due to the necessary

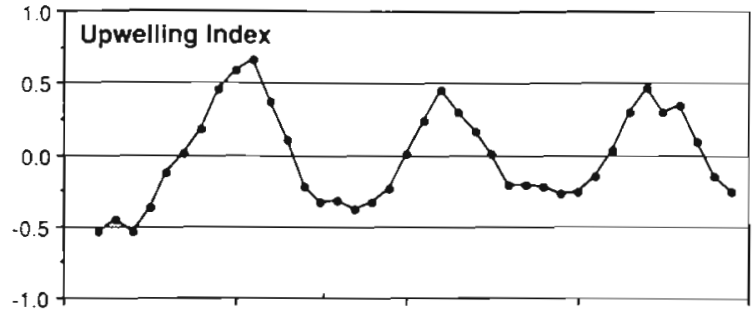

b

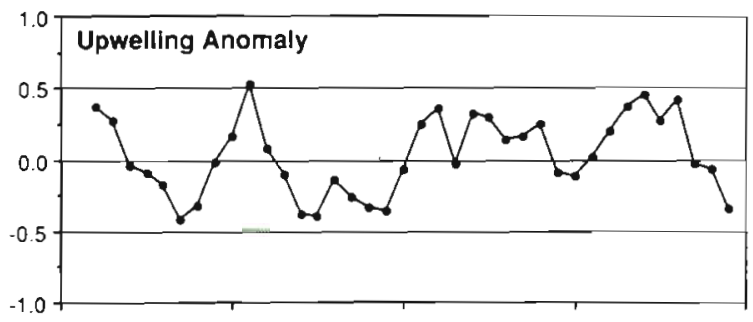

c

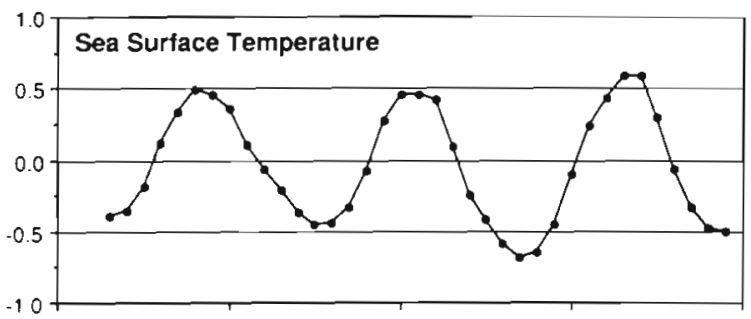

d

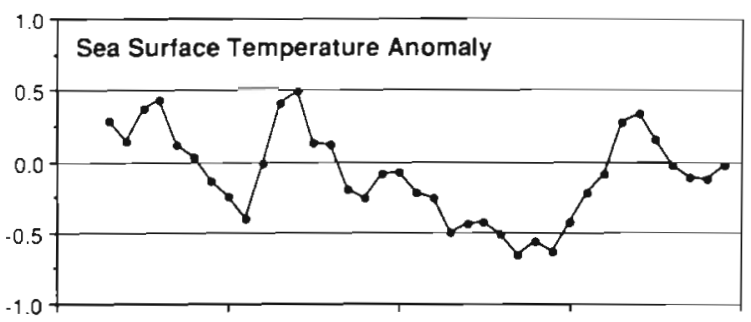

$\theta$

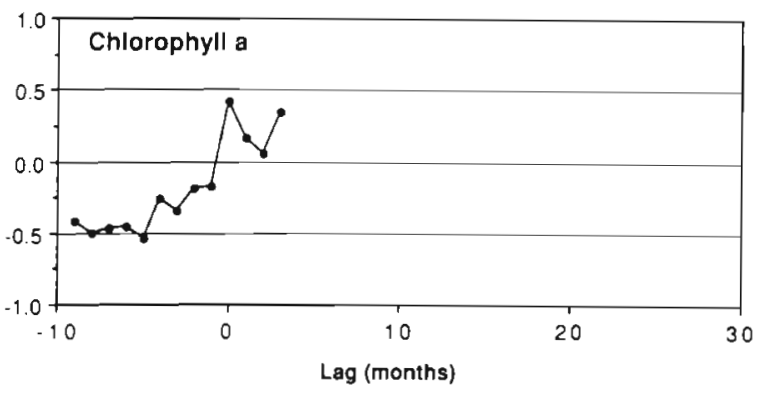

Fig. 6. Correlation coefficients $(I)$ for percentage cover of Phragmatopoma lapidosa californica and several physical parameters. In each case $n=15$ or 16 . (a) Index of coastal upwelling; (b) anomaly from the long-term mean index of coastal upwelling. (c) Sea surface temperature (d) anomaly from the long-term mean temperature. (e) Concentration of chlorophyll a at the Scripps Institution of Oceanography pier

exclusion of 2 dates with missing chlorophyll a data. For 3 and 5 mo time lags, wave power is by far the most highly correlated factor. 
Table 1 Phragmatopoma lapidosa californica. Stepwise multiple regression results for potentially important factors on percentage cover (arcsine transformed). Table values are partial correlation coefficients $\left(r^{2}\right)$ for the multiple regression which qualified $(p<0.10)$ for inclusion in the model

\begin{tabular}{|lccc|}
\hline Factor & 0 mo & 3 mo & 5 mo \\
\hline Wave power & - & 0.659 & $0.735(0.854)^{\circ}$ \\
Upwelling index & 0.351 & 0.069 & - \\
Chlorophyll a conc. & - & - & 0.066 \\
Sea surface temp. & - & - & - \\
Total & 0.351 & 0.728 & 0.801 \\
Number in parentheses includes 16 dates for analysis; \\
$\begin{array}{l}\text { Nher values for 5 mo include only } \\
\text { of data points because } \\
\text { of missing data for chlorophyll a }\end{array}$ \\
\hline
\end{tabular}

\section{DISCUSSION}

Several mechanisms may produce the correlation between Phragmatopoma lapidosa californica abundance and wave energy. Recruitment strength and subsequent percentage cover is regulated in part by the interplay of larval abundance and suitable settlement space. Disastrous storms may directly and indirectly control both of these factors by affecting spawning patterns, larval survivorship, growth, and transport and settlement success (by the creation of open space). Reproductive output is increased during severe storms by the destruction of aggregations and the release of gametes into the water column. Gamete release in response to tube breakage very likely affects temporal patterns of larval abundance. Unfortunately, the abundance of larvae in the plankton and the condition of gonads for any surviving individuals were not inves. tigated during this study. During Jensen's (1986) study of the abundance of larvae and settlement rates for $P .1$. californica in Goleta Bay, near Santa Barbara, California, which overlapped this study, peaks in settlement density on artificial settlement plates occurred during March, ca 1 mo after an extreme wave event. However, the greatest density of competent larvae in the water column was found during early May, 2.5 to 3 mo after the extreme wave events. These data corroborate, in part, the hypothesis of a facultative reproductive response to disturbance, but do not distinguish this response, if any, from simple seasonal reproductive periodicity; further study is required to better evaluate this relationship

The survivorship and shoreward transport of larvae may be indirectly affected by the effects of severe storms on the extent of offshore kelp beds (Dayton \& Tegner 1984, Ebeling et al. 1985, Gaines \& Roughgar- den 1987). Plantivorous fishes which prey on invertebrate larvae are abundant in coastal kelp beds and have significant negative effects on the shoreward flux of larvae (Gaines \& Roughgarden 1987). In addition, the shoreward transport of some larvae by surface slicks associated with internal waves (Shanks 1983) may be interrupted by the attenuation of internal waves by kelp beds (Jackson 1984); kelp beds, however, were poorly developed near the study site during the study period. Moreover, Phragmatopoma lapidosa californica larvae are physically defended by numerous large spines during their larval life. Trochophore larvae from related sabellariids with virtually identical larval morphology are rejected by several planktivorous species including a ctenophore, medusae, brachyuran megalopae, juvenile Sebastes spp., (Pennington \& Chia 1984), and other small fishes (Wilson 1929).

Increased settlement success may also be due to the creation of open space by large storms. If the abundance of larvae is normally high relative to the availability of settlement space, recruitment should occur whenever free space is created. Conversely, if the abundance of its larvae is limiting, open space will not be colonized by Phragmatopoma lapidosa californica. That recruitment is indicative of larval abundance is corroborated by the similar pattern of recruitment to artificially-cleared plots and unmanipulated plots with little free space during 1983 to 1985. Furthermore, settlement rates of $P$. l. californica near Santa Barbara were significantly correlated to the abundance of competent larvae in net tows (Jensen 1986). Thus, while several processes may be involved, the available evidence strongly suggests that changes in the abundance of larvae, rather than an increase in settlement space, was the primary cause of peaks in recruitment; moreover, increases in larvae abundance leading to recruitment appear to be closely related to a facultative spawning response to severe disturbances.

Irrespective of the relative importance of various storm-related processes, Phragmatopoma lapidosa californica exhibits several noteworthy adaptations that allow persistence under a complex disturbance regime. Its reproductive biology appears to constitute a 'bet-hedging' adaptive tactic which, like analogous species in other systems (i.e. fire-adapted species in terrestrial plant communities), minimizes the probability of recruitment failure. First, it has 3 temporal scales of reproductive effort: (1) low level continuous spawning, (2) seasonal spawning peaks (probable), and (3) a facultative response to disastrous events. Continuous low level reproductive output produces some larvae for settlement during periods when recruitment is usually improbable, except on existing aggregations. If $P$. 1 . californica has seasonal reproductive peaks similar to other sabellariids, as indicated by patterns of settle- 
ment and larval abundance (Taylor \& Littler 1982, Swarbrick 1984, Jensen 1986), these seasonal peaks likely precede peaks in the availability of settlement space or are timed to coincide with high phytoplankton abundance or both in order to promote larval growth and survival. Perhaps most important, a facultative 'event scale' response will maximize reproductive effort when the probability of future reproduction is low (due to imminent death) and the potential for successful settlement and recruitment is high due to reduced competition. Finally, because colonial life has obvious advantages (greater survivorship, longer life, higher fertilization succes), P. l. californica further reduces the probability of recruitment failure in several ways such as: delayed metamorphosis, gregarious settlement, and chemically-cued metamorphosis.

Life history tactics which provide multiple temporal scales of reproductive effort and are coupled to environmental cues are well documented from terrestrial communities, especially in fire-controlled communities (White 1979), but have not yet been reported from marine systems. If the adaptive tactics of a species include a reproductive commitment regulated by disturbance, then disastrous or catastrophic disturbances should initiate a recruitment response commensurate with their severity. The above data suggest that this phenomenon occurred in Phragmatopoma lapidosa californica populations during the 1982-1983 winter storms. The recruitment patterns of other coastal marine species, particularly those sensitive to disturbances, may be similarly influenced by the interaction of seasonally predictable, but inter-annually unpredictable disturbance regimes with evolutionarily-derived reproductive strategies. For example, mussels Mytilus spp. and gooseneck barnacle Pollicipes polymerus are aggregated, settle gregariously on conspecifics, and have irregular recruitment patterns which may be related to disturbance (Paine 1974). Of several factors tested, agitation of groups of Mytilus californianus in seawater, tension on byssal threads, or the presence of conspecific gametes in the water were the strongest spawning stimuli for this species (Young 1945). The abundance of $P$. polymerus followed a pattern very similar to $P$. l. californica during the study period and also may have reproductive or life history responses to severe disturbances. Closer examination of these species and other marine invertebrates and plants may reveal that their population dynamics are more closely tied to physical disturbance than previously thought.

Acknowledgements. Versions of the manuscript were greatly improved by P. Dayton, A. Genin, F. Jara, S. Jones, R. Paine, D. Reed, W. Sousa, W. Stockton, and M. Tegner and 2 anonymous reviewers. This research was supported in part by a grant from the Sigma-Xi Society.

\section{LITERATURE CITED}

Anon. (1978-1987). Coastal data inform. program. Vol. 65-132 Biswell, H. H. (1975). Effects of fire on chaparral. In: Kozlowski, T T., Ahlgren, C. E., (eds.) Fire and ecosystems, Academic Press, New York, p. 321-364

Christensen, N. L. (1985). Shrubland fire regimes and their evolutionary consequences. In: Pickett, S. T A., White, P. S., (eds.) The ecology of natural disturbance and patch dynamics. Academic Press, New York, p. 86-100

Curtis, L. A. (1978). Aspects of the population dynamics of the polychaete Sabellaria vulgaris Verrill, in the Delaware Bay. Estuaries 1: 73-84

Dales, R. P. (1952). The development and structure of the anterior region of the body in the Sabellariidae, with special reference to Phragmatopoma californica. Q. Jl microsc. Sci. 93: 435-452

Dayton, P. K. (1975). Experimental evaluation of ecological dominance in a rocky intertidal algal community. Ecol. Monogr. 45: 137-159

Dayton, P. K., Tegner, M. J. (1984). Catastrophic storms, El Niño, and patch stability in a Southern California kelp community. Science 224: 283-285

Ebeling, A. W., Laur, D. R., Rowley, R. J. (1985). Severe storm disturbance and reversal of community structure in a southern California kelp forest. Mar. Biol. 84: 287-294

Ebert, T. A., Russell, M. P. (1988). Latitudinal variation in size structure of the west coast purple sea urchin: a correlation with headlands. Limnol. Oceanogr. 33: 286-294

Eckelbarger, K. J. (1975). Developmental studies of the postsettling stages of Sabellaria vulgaris (Polychaeta: Sabellariidae). Mar. Biol. 30: 137-149

Eckelbarger, K. J. (1977). Larval development of Sabellaria floridensis from Florida and Phragmatopoma californica from southern California (Polychaeta: Sabellariidae), with a key to the sabellariid larvae of Florida and a review of development in the family. Bull mar. Sci. 27: 241-255

Eckelbarger, K. J. (1978). Metamorphosis and settlement in the Sabellariidae. In: Chia, F., Rice, M. E. (eds.) Settlement and metamorphosis of marine invertebrate larvae. Elsevier, New York, p. 145-164

Frost, P. G. H. (1984). The responses and survival of organisms in fire-prone environments. In: Booysen, P. De V., Tainton, N. M. (eds.) Ecological effects of fire in South African ecosystems. Springer-Verlag, New York, p. 273-310

Gaines, S. D., Roughgarden J. (1987). Fish in offshore kelp forests affect recruitment to intertidal barnacle populations. Science 235: 479-481

Gill, A. M. (1981). Adaptive responses of Australian vascular plant species to fires. In: Gill, A. M., Groves, R. H., Noble, I. R. (eds.) Fire and the Australian biota. Australian Academy of Sciences, Canberry, p. 243-272

Gruet, Y (1986). Spatio-temporal changes of Sabellarian reefs built by the sedentary polychaete Sabellaria alveolata (Linne) P.S.Z.N.I Mar. Ecol. 7: 303-319

Gruet, Y., Lassus, P. (1983). Contribution a l'étude de la biologie reproductive d'une population naturelle de l'annelide polychete Sabellaria alveolata (Linne). Annls Inst. océanogr., Paris 59: 127-140

Harper, J. L. (1977). Population biology of plants. Academic Press, New York

Jackson, G. A. (1984). Internal wave attenuation by coastal kelp stands. J. phys. Oceanogr. 14: 1300-1306

Jensen, R. A. (1986). Factors affecting the settlement, metamorphosis and distribution of larvae of the marine polychaete Phragmatopoma californica (Fewkes). Ph. D. dissertation, Universtiy of California, Santa Barbara 
Jensen, R. A., Morse, D. E. (1984). Intraspecific facilitation of larval recruitment: gregarious settlement of the polychaete Phragmatopoma californica (Fewkes). J. exp. mar Biol. Ecol. 83: 107-126

Kirtley, D. W. (1968). The reef builders. Nat. Mist. 77: 40-45

McLellan, H. J. (1965). Elements of physical oceanography. Pergammon Press, New York

Morris, R. H., Abbott, D. P., Haderlie, E. C. (1980). Intertidal invertebrates of California. Stanford University Press, Stanford, California

Muller, C. J., Hanawazit, R. B., McPherson, J. K. (1968) Allelopathic control of herb growth in the fire cycle of California chaparral. Bull. Torrey bot. Club 95: 225-231

Paine, R. T (1974). Intertidal community structure: experimental studies on the relationship between a dominant competitor and its principal predator Oecologia (Berl.) 15 $93-120$

Paine, R. T (1979). Disaster, catastrophe, and local persistence of the sea palm Postelsia palmaeformis. Science 205: $685-687$

Paine, R. T., Levin, S. A. (1981). Intertidal landscapes: disturbance and the dynamics of pattern. Ecol. Monogr 51 $145-178$

Pawlik, J. R. (1986). Chemical induction of larval settlement and metamorphosis in the reef-building tube worm Phragmatopoma californica (Polychaeta: Sabellarijdae). Mar Biol. $91.59-68$

Pawlik, J. R. (1988). Larval settlement and metamorphosis of Sabellariid polychaetes, with special reference to Phrag. matopoma lapidosa, a reef-building species, and Sabellaria floridensis, a non-gregarious species. Bull. mar. Sci. 43: $41-60$

Pawlik, J. R., Faulkner, D. J. (1986). Specific free fatty acids induce larval settlement and metamorphosis of the reefbuilding tube worm Phragmatopoma californica (Fewkes) J. exp. mar. Biol. Ecol. 102: 301-310

Pennington, J. T. Chia, F. S. (1984). Morphological and behavioral defenses of trochophore larvae of Sabellaria cementarium (Polychaeta) against four plantonic predators. Biol. Bull. mar biol. Lab. Woods Hole 167 : $168-175$

Pickett, S. T A., White, P. S. (1985). The ecology of natural

This article was presented by Professor N. D. Holland,

La Jolla, California, USA disturbance and patch dynamics. Academic Press, New York

Roughgarden, J., Gaines, S., Possingham (1988). Recruitment dynamics in complex life cycles. Science 241: 1960-1966

Seymour, R. J., Strange, R. R. III, Cayan, D. R., Nathan, R. A (1984). Influence of El Niños on California s wave climate. Nineteenth Coastal Engineering Conference, Proceedings of the International Conference, September 3-7, 1984. American Society of Civil Engineers, New York

Shanks, A. L. (1983). Surface slicks associated with tidally forced internal waves may transport pelagic larvae of benthic invertebrates and fishes shoreward. Mar Ecol. Prog. Ser 13: 311-315

Shanks, A. L.., Wright, W. G. (1986). Adding teeth to wave action: the destructive effects of wave-borne rocks on intertidal organisms. Oecologia (Berl.) 69: 420-428

Suchanek, T H. (1981). The role of disturbance in the evolution of life history strategies in the intertidal mussels Mytilus edulis and Mytilus californianus. Oecologia (Berl.) 50: $143-152$

Swarbrick, S. L. (1984). Disturbance, recruitment and competition in a marine invertebrate community. Ph. D. dissertation, University of California, Santa Barbara

Taylor, P. R., Littler, M. M. (1982). The roles of compensatory mortality, physical disturbance, and substrate retention in the development and organization of a sand-influenced, rocky-intertidal community. Ecology 63: 135-146

White, P. S. (1979). Pattern, process, and natural disturbance in vegetation. Bot. Rev. 45: 229-299

Wilson, D. P. (1929). The larvae of British Sabellarians. J. mar. biol. Ass. U. K. 16: 221-269

Wilson, D. P. (1970). Additional observations on larval growth and settlement of Sabellaria alveolata. J. mar biol. Ass. U.K. 50: $33-52$

Wilson, D. P. (1971). Sabellaria colonies at Duckpool, North Cornwall, 1961-1970. J. mar biol. Ass. U. K. 51: 509-580

Young, R. T (1942). Spawning season of the California mussels, Mytilus californianus. Ecology 23: 490-492

Young, R. T. (1945). Stimulation of spawning in the mussel (Mytilus californianus). Ecology 26: 58-69

Young, R. T (1946). Spawning and setting season of the mussel, Mytilus californianus. Ecology 27: 354-363

Revised manuscript accepted: March 17, 1989 